\title{
Deuda pública, mercado crediticio y actividad económica en la Casti- lla del siglo XVII ${ }^{*}$
}

\author{
Alberto Marcos Martín \\ Universidad de Valladolid
}

RESUMEN: Este trabajo versa sobre las consecuencias negativas que para el desenvolvimiento de la actividad económica y el desarrollo de un sistema virtuoso de incentivos trajo consigo, en la Castilla del siglo XVII, el crecimiento incesante, ya desde la centuria anterior, de la deuda consolidada en forma de juros. Buena parte de su contenido está dedicado, a su vez, a analizar las causas por las cuales esa clase de deuda se fue deteriorando y perdiendo cotización y rentabilidad. En él se presta también una especial atención al hecho de que la Monarquía, para cubrir sus necesidades monetarias y seguir captando el ahorro privado, no tuviera más remedio que manipular la deuda privada de los censos y servirse de ella para expandir su propia capacidad de crédito, para lo cual hubo de contar con la necesaria intermediación financiera de las haciendas locales, que de esta manera fueron puestas al servicio del crédito de la Corona.

Palabras Clave: Corona de Castilla; Edad Moderna; Deuda pública (juros); Actividades productivas; Crédito privado (censos); Haciendas municipales.

\section{Public Debt, Financial Markets and Economy in XVII ${ }^{\text {th }}$ Century Castile}

ABSTRACT: This essay deals with the negative consequences brought by the expansion of the consolidated debt since the XVIth century through the massive

* Este trabajo se ha realizado en el marco del Proyecto de Investigación HAR200912436HIST, «El producto agrario y el saldo vegetativo en la España del siglo XVIII. Crecimiento económico e inestabilidad», y en el seno del Grupo de Investigación Reconocido (GIR) de la Universidad de Valladolid «Grupo de estudios sobre la familia, cultura material y formas de poder en la España Moderna». Siglas: AGS: Archivo General de Simancas; CJH: Consejo y Juntas de Hacienda; CC. GG.: Contadurías Generales; DGT, invent. 24: Dirección General del Tesoro, inventario 24; MP: Mercedes y Privilegios. 
issues of long term annuities (juros) on the Castilian economy. The article analyses the reasons which reduced the appeal of these financial assets among private investors. This prompted the Royal Treasury to follow an alternative course and, trying to expand its credit base, the Crown resorted to the financial systems of the Castilian cities, which became closely subordinated to the needs of the Royal Treasury.

Key WORDS: Castile; Early Modern Period; Public Debt Assets (juros); Productive Economy; Private Credit (censos); Municipal Treasuries.

En la sesión de las Cortes de Castilla de 26 de marzo de 1615, correspondiente a las que se celebraron en Madrid durante algunos meses de dicho año, don Diego Gallo de Avellaneda tomó la palabra para pedir a sus compañeros de asamblea que se avinieran a suplicar a Su Majestad, mediante el pertinente memorial, que cesase «un medio que los genoveses hombres de negocios le propusieron, que es el que llaman general». La indeterminación con la que el procurador por Burgos se refería al objeto de su petición no significaba, ni muchos menos, que los demás procuradores ignoraran de qué estaba hablando ${ }^{1}$. Todos sabían, en efecto, que el mencionado medio general era el acuerdo suscrito el 14 de mayo de 1608 entre la Hacienda regia y los genoveses de los asientos afectados por el decreto de suspensión de consignaciones de 7 de noviembre de 1607 con el fin de cerrar y saldar cuentas y deudas pendientes; y, sobre todo, que ése era también el nombre, completado con el más pomposo de Diputación, que se había dado desde un principio a la agrupación de los más conspicuos de dichos asentistas encargada precisamente de llevar a cabo semejantes propósitos, para lo cual se la había dotado de amplias competencias sobre las finanzas públicas, las cuales comprendían no sólo el control y la intervención de los ingresos sino también la enajenación por precio de suculentos activos del patrimonio regio ${ }^{2}$.

De todas esas atribuciones, la que tenía en mente don Diego Gallo y motivaba su pronunciamiento era, señaladamente, la relativa al crecimiento de los juros, esto es, la facultad (o medio) concedida a los hombres de negocios genoveses para comprar títulos que corrían a 14.000 el millar y, al instante, volverlos a vender a 20.000 o más el millar, para así, con la diferencia, ir haciéndose pagados de los 12 millones de ducados que el monarca supuestamente les adeudaba. Se quejaba el procurador burgalés de que la operación en cuestión se hubiera dilatado más allá del tiempo previsto en un principio, y de que,

1 Actas de las Cortes de Castilla, XXVIII: 156-157. El otro procurador de la caput Castellae en aquellas Cortes fue el mismísimo duque de Lerma.

2 RUIZ MARTÍN, 1970: 45. 
habiéndose presentado como una operación de desempeño, estuviese siendo en la práctica de tan "poco y peligroso fruto» para Su Majestad, pues las bajadas del tipo de interés de los títulos que los referidos crecimientos comportaban, si bien suponían una reducción del volumen de los intereses a pagar por la Hacienda, empeñaban todavía más el principal y, consecuentemente, hacían aún más difícil la redención definitiva de esta clase de deuda. Ello venía a redundar, continuaba diciendo don Diego, «en daño universal del reino, en menoscabo de otras rentas, en perjuicio de los hospitales, monasterios y obras pías, en total destrucción de algunos lugares del reino y en la ruina de sus vasallos cuyas haciendas estaban en juros». Por el contrario, todo el provecho dimanante de lo que para él eran groseras manipulaciones de los tipos de interés se lo llevaban los genoveses, «en mala razón de Estado», ya que «se enriquecen con la hacienda de los naturales de estos reinos y —aspecto de la cuestión que le parecía todavía más intolerable — tocan con las manos la necesidad de Su Majestad» ${ }^{3}$.

El asunto volvió a ser tratado nada más abrirse, en 1617, las siguientes Cortes. Fue don Lorenzo Ramírez el que en la sesión de 12 de junio urgió al resto de procuradores a pedir al monarca que se dieran al Reino «enteras noticias y conocimiento» del medio general, ahora precisamente que se cumplía la última prórroga de su existencia ${ }^{4}$, para que, visto y entendido todo por él, se supiera con certeza el estado de la Real Hacienda y la situación en que se hallaba realmente el desempeño. Tres días después, los comisarios nombrados para ese cometido, entre los que se encontraba el propio Ramírez, tenían ya redactado el nuevo memorial que, una vez leído, se votó y acordó fuese enviado al monarca. Reiteraba el Reino que en él «no se sabe del efecto que ha sido [el medio general] ni si se ha conseguido el fin para que se hizo», a pesar de lo cual, convencido como estaba de las «excesivas ganancias» que los genoveses habían obtenido con su administración, pedía que cesase, solicitando además que sus actuaciones pasadas fueran verificadas. Una ulterior redacción del texto antes de su envío al monarca, traída a la sesión de 23 de junio, se hacía eco del rumor que había comenzado a correr por los mentideros de la Corte de que se iba a prorrogar por otros seis meses el tinglado montado por los asentistas genoveses $y$, en consecuencia, redoblaba su insistencia en que «de todo punto se acabe y deshaga» ${ }^{5}$.

La respuesta del monarca al memorial de las Cortes se hizo esperar. A decir verdad, dicha respuesta nunca tuvo lugar, y sólo cabe deducir su presumible

3 Actas, XXVIII: 156-157.

4 De las anteriores prórrogas se habla en una consulta del Consejo de Hacienda de 12 de abril de 1615 sobre el repartimiento que los diputados del medio general pidieron se les hiciese de los juros de él a cuenta de lo que todavía se les debía. AGS, CJH, leg. 536.

5 Actas, XXIX: 469-472, 487-489 y 544-545. 
contenido de la contestación dada, en este caso sí, por Felipe III a una consulta del Consejo de Hacienda, su fecha 3 de septiembre de 1617, sobre el mismo tema. Resulta más interesante en cualquier caso el documento del Consejo que la resolución regia, en tanto en cuanto suponía una cerrada defensa de la actuación de la Diputación y un alegato durísimo contra las pretensiones del Reino ${ }^{6}$.

Para empezar, todo el contenido del memorial denotaba, a juicio de los consejeros, que «no se tiene entendido en las Cortes lo que es el medio general, ni la justificación y conuencia [sic] del arbitrio del desempeño y crecimiento de juros [...] ni en cuyo beneficio se ha hecho, ni cómo ni con qué obligación lo an administrado los diputados del dicho medio». Desde luego, proseguía el Consejo, no se podía sostener, como pretendían los parlamentarios, que de pagar a los hombres de negocios lo que se les debía resultase algún inconveniente, ya que saldar las deudas pendientes constituía un acto de «justicia y de derecho natural». Más endeble aún se estimaba la crítica realizada por el Reino al uso que la Diputación hacía del arbitrio. Al fin y al cabo, los juros que se desempeñaban estaban vendidos con la condición expresa de poderse redimir en cualquier momento pagando su principal a los dueños. Es más, tampoco se perjudicaba a nadie por el hecho de que los juros redimidos se volviesen a vender a mayores precios, bien a los mismos dueños que los tenían, bien a terceros, porque «no se a hecho ni se haze con ningún género de fuerça sino voluntariamente, dándolos a quien los pide». En todo caso, el beneficio obtenido hasta la fecha certificaba sobradamente, en opinión del Consejo, la bondad del procedimiento: nada menos que 11,5 millones de ducados se habían sacado del arbitrio, con los cuales no sólo se había hecho la paga de lo que se debía a los hombres de negocios decretados en 1607 sino que todavía había sobrado para Su Majestad otro millón y medio de ducados limpios7.

También el «bien común y público», insistían los hombres de la Hacienda del rey, salía beneficiado con las operaciones del medio general. Concretamente, el desempeñar juros impuestos a precios bajos para volverlos a vender a otros más subidos constituía un arbitrio útil para el interés general en la medida en que, al rebajarse la rentabilidad de tales títulos casi una tercera parte (y, complementariamente, la de los censos), su ganancia colocábase automáticamente por debajo de la que se adquiría mediante la labranza y la crianza, la industria y el comercio, actividades hacia las que a partir de ahora, solventado aquel impedimento, fluiría el dinero. Más aún, si mediante un medio tan sencillo como éste se propiciaba el aumento de dichas ocupaciones y, con él, el de las rentas reales, también se evitarían aquellos otros efectos (de carácter moral en este caso) que de la vida ociosa y rentista se derivaban.

6 Así lo han valorado algunos autores como GELABERT, 1997: 46-48.

7 AGS, CJH, leg. 547. 
No deja de sorprender de todas formas el tono empleado en su discurso por quienes, habiendo gestionado la puesta en circulación de los juros y conociendo sobradamente sus repercusiones, venían a lamentarse ahora de las consecuencias negativas que para el positivo desenvolvimiento de la vida económica y el desarrollo de un sistema virtuoso de incentivos traía consigo el crecimiento incesante de la deuda consolidada ${ }^{8}$, presentando además como responsables únicos de estos y otros males a los compradores y tenedores de los susodichos títulos. Los mismos procuradores, al pedir que cesase una «cossa tan justificada y conuiniente», en vez de desear y buscar la forma para desempeñar y desahogar la Real Hacienda, daban, según los miembros del Consejo, muestras inequívocas de no pretender otra cosa que la perpetuación de los juros, revelándose, al cabo, como los portavoces de los intereses particulares del grupo jurista y no de los del común de la República. Ello naturalmente les deslegitimaba, una acusación que los consejeros lanzaban al final de su consulta, en la que, como remate, se atrevían a cuestionar no ya sólo el carácter y el poder de su representación parlamentaria sino su misma capacidad para enviar al monarca un memorial como el referido, exhortando en última instancia a éste a proceder contra ellos «con la severidad justa y deçente a su authoridad real, de manera que se entienda que [ni] los dichos procuradores de Cortes ni otra persona alguna tiene poder de çenssurar las acciones de su rey y señor, pues V. Magd. procede en todas con el consejo, prudençia y çelo del bien público de sus reynos y de toda la Christiandad....»9.

La intervención de la Diputación del medio general en la negociación del arbitrio del desempeño y crecimiento de juros expiró a finales de $1617^{10}$. Cesaron, pues, los diputados, pero no así la citada negociación por la utilidad que los consejeros de Hacienda presumían se podía seguir sacando de ella, más aún a partir de ahora en que, satisfecha la paga de lo que se debía a los hombres de negocios genoveses, todo el beneficio que se obtuviere ingresaría

8 Con palabras que no tienen desperdicio y que, por ello, no me resisto a reproducir: «porque siendo el trato y el comercio y labrança y criança y el exerciçio de las cossas que se hazen por arte e industria la sustancia y neruio de la conseruación y augmento de los reynos, en estos de Castilla está muy caído todo esto. Y una de las caussas a sido la gran dispussiçión que ha auido en ellos de juros y çenssos a precios tan acomodados que se a tenido su ganançia por maior que la del trato y comerçio, labranza y crianza. Y como todos procuran emplear su haçienda en aquello que mayor benefiçio y con menos trauajo de sus personas pueden sacar della, allando estas comodidades en los juros y çenssos, se an inclinado a comprarlos y viuir con su renta, sin meterse en los cuidados con que se exerçita todo género de contratación, de que también ha resultado el hazerse la gente ociossa, que es quien más a sentido el dicho arbitrio». AGS, CJH, leg. 547.

9 AGS, CJH, leg. 547.

10 Se afirma categóricamente tal cosa en una consulta del Consejo de Hacienda de 8 de julio de 1618 en la que se daba nueva respuesta a la que había dado Su Majestad a la ya referida consulta de 3 de septiembre de 1617. AGS, CJH, leg. 555. 
enteramente en las arcas del rey. De hecho, a la propuesta efectuada en este sentido por el Consejo de Hacienda en consulta de 8 julio de 1618, Felipe III no dudó en responder: «continúese esta negociaçión por dos años y después se verá lo que convendrá para adelante» ${ }^{11}$.

Desde luego no era baladí el negocio que se ventilaba, consistente, en definitiva, como bien señalaba Gaspar de Pons en voto particular incorporado a la citada consulta, en «reducir a padecer menos intereses el empeño de la Real Hacienda». No en balde, por esas fechas se estaban pagando en los reinos de Castilla en concepto de réditos de juros más de cinco millones de ducados cada año y, si se tenía «buen cuidado», era factible reducir esa cantidad a menos de tres, con lo que en la operación se ganarían dos millones de renta. Más aún, si se pusiera «mucho cuidado» en la susodicha empresa, se podría desempeñar todo lo empeñado y aprovecharse enteramente el monarca para el porvenir de esos más de cinco millones. Es cierto que para conseguir tales objetivos se necesitaba tiempo, pero no había otro camino, aseguraba el ilustre consejero, si de verdad se quería aliviar a los vasallos de estos reinos «de las muchas cargas que pagan».

Quienes no querían ni oír hablar de esta forma de desempeño eran los representantes en Cortes. Bien mirado, sin embargo, tales preocupaciones carecían de fundamento, pues lo cierto es que la Corona carecía de medios con que redimir (amortizar) los juros puestos en circulación, y tampoco hallaba dinero con qué crecerlos ${ }^{12}$. Además, la situación financiera, una vez que la crisis de Bohemia (mayo de 1618) hubo encendido de nuevo las hogueras de la guerra en Europa, avivadas tras la ruptura de la tregua en Flandes (abril de 1621), acontecimientos que forzarían a partir de ahora un incremento constante de los gastos, se tornó cada vez más complicada y terminó por aparcar aquella posibilidad. A lo que no podía renunciar la Corona, empero, era a aliviarse del peso de una deuda, ésta de los juros, que la estaba asfixiando al consumir todos sus ingresos ordinarios. Y, en efecto, lo intentará, sirviéndose de una fórmula bastante más expeditiva y destemplada a la postre que aquella que tanto habían temido las Cortes, esto es, decretando unilateralmente la rebaja del tipo de interés que retribuía dichos títulos.

Así, una pragmática de 7 de octubre de 1621, promulgada al día siguiente, extendía a los juros y censos ya constituidos lo que la ley de 1608 había dis-

11 AGS, CJH, leg. 555.

12 Ésa y no otra fue la razón que motivó la escasa actividad de la «nueva negociación», la cual, sin embargo, continuaría funcionando en los años siguientes, como se desprende de la orden dada por Felipe IV desde Zaragoza el 29 de septiembre de 1644 para que don Pedro Valle de la Cerda prosiguiese en lo tocante a la superintendencia del medio general de 14 de mayo de 1608 en lugar de Ipeñarrieta, a cuyo cargo había estado. AGS, CJH, leg. 864. 
puesto en principio sólo para los que se hubiesen de fundar en el porvenir ${ }^{13}$, de suerte que quedase hecha la reducción y baja de la renta de todos a razón de a 20.000 el millar, «y a este respecto se cuenten y paguen adelante, y no a más» ${ }^{14}$. La citada pragmática insistía, por otro lado, en la conveniencia de que juros y censos corrieran «a un mismo tiempo», y ello por una razón que no se mencionaba expresamente, no fuese a ocurrir que el ahorro de los particulares, al cual la Monarquía tendría necesidad de seguir apelando, fluyese con preferencia a la compra de deuda privada en lugar de a la adquisición de deuda pública. Naturalmente, el Reino reaccionó al instante recuperando y volviendo a poner sobre la mesa una proposición que, cuando se planteó por primera vez ${ }^{15}$, los procuradores desestimaron elevar a Su Majestad: éste venían a sostener - no podía crecer los juros a mayores precios «sin dar a los dueños dellos el dinero como ay obligación, por ser contrato mutuo y reçíproco, y condición espresa de los preuilegios» ${ }^{16}$. De nada servirían, sin embargo, dichas quejas; el crecimiento de los juros, tal como ahora se concebía, comenzó a ejecutarse inmediatamente, y al Reino no le quedó otro consuelo que incluir su petición entre las condiciones del servicio de millones de 1632 en un intento de evitar que decisiones como éstas se repitiesen en el futuro ${ }^{17}$.

Teóricamente, esta disposición de 1621 debería haber procurado para lo sucesivo un alivio considerable a la Real Hacienda, puesto que de la noche a la mañana el situado o suma de los intereses a pagar por los juros no comprendidos en la pragmática de 1608, que eran la mayoría, se reducía en una tercera parte aproximadamente, o sea, más o menos en la proporción estimada por Gaspar de Pons en la consulta de 8 de julio de 1618 ya citada. En la práctica, sin embargo, el alivio fue sólo momentáneo. Y es que si el situado de los juros continuó remontando con posterioridad, como en efecto así ocurrió, ello se debió a que no dejaron de producirse, entre tanto, nuevas emisiones de títulos.

Tres corrientes principales siguieron alimentando en el transcurso del siglo XVII el caudal de juros en circulación ${ }^{18}$. De un lado, las compensaciones realizadas a comerciantes y hombres de negocios por los secuestros de metales preciosos americanos consignados a su nombre, desempeñaron un cierto pa-

13 Dicha ley (pragmática de 26 de enero de 1608) contemplaba también el crecimiento de los juros perpetuos de 14 a 20.000 el millar; al tiempo que subía los de por una vida a 10.000 y los de por dos vidas a 12.000 el millar. Ley 12, tit. XV, libro V de la Nueva Recopilación.

14 Una copia manuscrita de esta pragmática, que pasó a la Nueva Recopilación como la ley 13, tit. XV, lib. V, puede verse en AGS, CJH, leg. 580.

15 Actas, XXXII: 152-153.

16 Actas, XXXVII: 132.

17 Se hizo cédula de dicha condición, su fecha 27 de julio de 1632. Vid. tit. XV, lib. V de la Nueva Recopilación. La misma condición se impuso en Cortes posteriores.

18 Para más información, DOMÍNGUEZ ORTIZ, 1960: 318 y ss., y TOBOSO SÁNCHEZ, 1987: 159-166. También MARCOS MARTÍN, 2006: 345-375. 
pel; como sin duda lo tuvieron, y en mayor medida si cabe, las indemnizaciones hechas a los mismos poseedores de títulos por los descuentos y valimientos efectuados en los réditos de sus juros, práctica que se reiteraría año tras año (con contadas excepciones) a partir de 1635: pues bien, en ambos casos la entrega de nuevos juros en pago de las cantidades secuestradas y/o retenidas fue la conducta seguida habitualmente por la Hacienda regia. Hubo, en segundo lugar, diversas ventas forzosas de títulos a lo largo de la centuria que contribuyeron igualmente a alimentar aquella corriente, la más sonora y extendida de las cuales, pues motivó incluso la elaboración de un recuento de población a escala de toda la corona de Castilla, fue la que se realizó en 1646. Con todo, la mayor parte de las emisiones de juros durante el siglo XVII, en una proporción que Pilar Toboso ha estimado en un 70 por 100 de todos los títulos emitidos a partir de $1626^{19}$, lo fueron para reembolsar a los hombres de negocios lo que se les adeudaba por los principales e intereses de sus asientos, luego de las sucesivas suspensiones de pagos decretadas a lo largo de la centuria ${ }^{20}$, aunque para ser precisos se emitieron también juros con el fin de entregarlos, a falta de consignaciones mejores, a los asentistas en pago y/o resguardo de sus anticipos, eso sí, siempre con los correspondientes premios o quebrantos para la Real Hacienda, ya que de otro modo no los hubieran aceptado.

Así pues, y como consecuencia de la intervención de este triple conjunto de factores, el importe del situado de los juros, que en 1598 ascendía a 1.737.860.239 mrs., alcanzó en 1623 los 2.110.125.000 mrs., para remontar hasta los 2.407.030.838 mrs. en $1637^{21}$. Apenas un año después, según la cuenta que hicieron los contadores de relaciones con el fin de determinar si podían obtenerse los dos millones de ducados en plata de que Su Majestad había resuelto valerse, gravando para ello a los juristas, la renta de los juros situados en alcabalas, millones y otros ingresos de la Corona era de 2.470.780.858 mrs., que hacían 6.588.749 ducados²2, equivalentes a un nominal en circulación de unos 130 millones de ducados. Y, sin embargo, aún no

19 TOBOSO SÁNCHEZ, 1987: 161 y 166.

20 Cfr. SANZ AYÁN, 2000: 727-750.

21 Son las cifras que da DOMÍNGUEZ ORTIZ, 1960: 325 y que han reproducido otros autores después.

22 Venía a montar el medio año, por lo tanto, 3.294.374 ducados, de los cuales se bajaban 250.000 ducados que se habían de reservar para hospitales, conventos y obras pías no afectados por el descuento y otros 115.757 ducados por diferentes conceptos. Quedaba la media anata, pues, en 2.928.617 ducados, que al bajarse 139.458 por la conducción a razón del $5 \%$ se convertían en 2.789.160 ducados, de los cuales, una vez reducidos a plata con $25 \%$ de premio, restaban para poder valerse Su Majestad 2.231.328 ducados de plata. Sobraban todavía, por esta cuenta, 231.328 ducados, que habrían de reservarse para lo que pudiesen importar los «mayores trueques» de plata por vellón y para suplir lo que saliera incierto por las quiebras de tesoreros de las mismas rentas y otros accidentes. AGS, CJH, leg. 777. 
se había llegado a los niveles que serían corrientes más tarde, según testimonian algunos de los cálculos de los que tenemos noticia: 3.430.252.875 mrs. en 1667 ; 4.181.032.700 mrs. en 1687; 7.339.300.905 mrs. en $1714 . .$. ; o lo que es lo mismo, 9,1, 11,1 y 19,5 millones de ducados respectivamente, sólo en concepto de situado se precisará23. Es decir, ni los desempeños y crecimientos de juros efectuados por los diputados del medio general de 14 de mayo de 1608, ni el descenso legal (pragmáticas de 1608 y 1621) del tipo de interés que los retribuía, ni tan siquiera la caída progresiva de la rentabilidad de los títulos por mor de estas y otras circunstancias, fueron factores suficientes para quebrar una evolución que, en la media y larga duración al menos, siguió una trayectoria marcadamente ascendente.

Las cifras anteriores deben contemplarse, no obstante, desde una perspectiva más teórica que real, habida cuenta de que la Hacienda regia no pagaba enteramente el situado de los juros que empeñaba sus rentas ordinarias, y enseguida también parte de las extraordinarias ${ }^{24}$. La misma multiplicación de los títulos, unida a la paralela mengua del valor de las rentas sobre las que se situaban, en un contexto obstinadamente recesivo como el que caracteriza a buena parte del siglo XVII, produjo desde fechas relativamente tempranas fenómenos de no cabimiento, en virtud de los cuales los juros que no cabían, por exceder la suma de sus intereses de las cantidades recaudadas, dejaban de pagarse o se pagaban sólo en la parte correspondiente y proporcional al producto realmente obtenido de las rentas que los sustentaban.

Pero el crédito de los juros no sólo se vio afectado por esta circunstancia o por el exceso de los mismos. La propia Corona le iba a asestar un duro golpe desde que comenzara a retener una parte de los réditos que debía hacer buenos a los juristas sin otra justificación o fundamento que la apelación a la necesidad pública y a los aprietos de la Hacienda. Semejantes deducciones o valimientos se institucionalizaron a partir de 1635, año de la entrada de Francia en la guerra de los Treinta Años, siendo por otro lado los descuentos realizados cada vez mayores, pues a los primeros siguieron enseguida otros adicionales ${ }^{25}$; además, si en un principio tales retenciones se hicieron pasar por

23 Para 1667 y 1687, véase DOMÍNGUEZ ORTIZ, Antonio, 1960: 325-326 y SÁNCHEZ BELÉN, 1996: 87 y ss. (este autor da además para 1669 la cifra de 9.986.513 ducados); y para 1714, TOBOSO SÁNCHEZ, 1987: 173.

24 Ya en la consulta del Consejo de Castilla sobre el remedio universal de los daños del reino y reparo de ellos, de 1 de febrero de 1619, se reconocía «la falta de haçienda con que V. M. se halla, que, aunque es mucha, está toda consumida y empeñada, salvo la que no es fixa ni segura, como son las tres gracias, el servicio ordinario y extraordinario, y el de los millones, y la flota de las Indias, que no puede llegar ni llega con gran parte al gasto preçiso y forzoso, de que se considera oy tiene V. M. neçesidad para sustentar el peso grande deste tan estendido imperio y monarquía». GONZÁLEZ PALENCIA, 1932: 16 (doc. IV).

25 Una relación detallada de estos descuentos y valimientos, con indicación de los porcentajes retenidos en cada caso, puede verse en TOBOSO SÁNCHEZ, 1987: 176-177, que 
préstamos forzosos reembolsables con nuevos juros ${ }^{26}$ e incluso se brindó a los juristas la oportunidad de utilizar su importe como moneda de cambio para comprar bienes y efectos del patrimonio regio que se enajenaban, en breve hubo que desistir de estos ofrecimientos por imposibilidad material de responder a ellos.

Es decir, si la evolución del montante de los juros (al que habría que sumar, de otro lado, el ascendiente de la deuda flotante de los asientos) permite estimar, como señalara Felipe Ruiz Martín, la erosión persistente, continuada, del crédito público sobre el crédito privado, la asignación no menos constante y prolongada de capital a usos diferentes de los que requería el crecimiento económico, la detracción en definitiva de la oferta monetaria en términos equivalentes a los representados por dicha magnitud, sin que el oro y la plata llegados de América compensasen tal sustracción, pues esos metales, más pronto que tarde, se expedían fuera, por diversos conductos, legales unos, fraudulentos otros ${ }^{27}$, no se puede dejar de considerar asimismo que esa erosión se acentuó a partir de 1635, precisamente cuando la Corona procedió a descontar y valerse de una parte - igualmente creciente a causa de la adición de sucesivos cargos y recargos- de los intereses de los títulos, decisión que significaba que en adelante los juristas quedaban privados también de esa porción, no pequeña precisamente, del fruto de sus inversiones.

En una larga carta escrita por la ciudad de Sevilla, el 14 de abril de 1643, en la cual solicitaba al monarca que suspendiera la ejecución de la cobranza de la media anata de los juros de este año y que en los de adelante no usase de medio «tan gravoso y penoso», se ilustraban las sucesivas detracciones que ya por entonces sufrían los juros de la siguiente manera. A una persona que tuviera 2.000 ducados de renta no le quedaban netos en realidad más que 220 ducados, o sea, el $11 \%$ del total teórico. Para empezar, de los 1.000 ducados de la mitad de que se servía Su Majestad, sólo podía sacar, en los juros que se le daban a modo de satisfacción, 120 ducados efectivos después de descontadas las pérdidas que aquéllos sufrían, estimadas en un 88 \%. En segundo lugar, los 1.000 ducados de la otra mitad experimentaban también una pérdida considerable, debido más que nada a su «dificultosísima y dilatada» cobranza luego de que se hubiere sacado la mitad de que se valía el monarca («de lo

sigue en esto a Ripia, Juan de la, Práctica de la administración y cobranza de las rentas reales y visitas de los ministros que se ocupan de ellas, págs. 200-209. Para el reinado de Carlos II, son muy atinados los comentarios de SÁNCHEZ BELÉN, 1996: 87 y ss.

26 Como decía el Consejo de Hacienda en consulta de 13 de julio de 1643 «siempre se a entendido que el pretesto con que V. Md. se siruió de balerse de las medias annatas de juros fue de que no hera hazer toma dellos sino comutación de la paga de un efecto a otro dando satisfacción a sus dueños de lo que montasen los réditos de que V. Md. se baliese...». AGS, CJH, leg. 852.

27 Véase, entre otros trabajos RUIZ MARTÍN, 1975: 738-743. 
más pronto y cobrable»), pérdida o desestimación que se cifraba en este año en un 50 \% y que, según los munícipes sevillanos «cada día se juzga ha de ser mayor». En fin, puesto que muchos juros tenían sobre sí cargas de alimentos, capellanías, obras pías, tributos y obligaciones diversas, cuya cobranza y paga era ejecutiva y debía hacerse enteramente, todavía había que restar, de los 500 ducados netos que le quedaban de esta segunda mitad, una quinta parte al menos de la renta teórica total, esto es, otros 400 ducados $^{28}$. Consecuentemente, al hipotético jurista sólo le quedaban líquidos 220 ducados.

Está claro que una reducción tan drástica de las rentas de los juristas, aun cuando no fuera exactamente de esa magnitud y debamos cuestionar la validez de los cálculos hechos para llegar a ella, tenía que incidir negativamente en la economía de una urbe como Sevilla, en este caso como consecuencia de la contracción del gasto y del consumo, máxime siendo el grupo de los juristas «el mayor y más principal de la uesindad desta ciudad y que la ase de población lucida y numerosa». Aseguraban los veinticuatros sevillanos que los juristas gastaban y consumían sus rentas en el sustento de sus casas y familias, sin reservar cantidad alguna, «como azienda destinada para solo este fin». Con ella mantenían criados, hacían limosnas, socorrían a los religiosos y obras pías y sustentaban a los oficiales «de todos géneros que siruen a la República» y a los mercaderes de todas las clases; incluso los pobres que hilaban y labraban la lana se beneficiaban de ella, «por el orden del trato, dependencia y comunicación de las gentes entre sí». Dicho con otras palabras, si todos venían a vender sus frutos y manufacturas a una ciudad como Sevilla, si ésta había llegado a ser tan grande y populosa, ello se debía, básicamente, a lo que "gastan y consumen sus vecinos con las rentas que goçan, que todas se conbierten en estos usos, con que se compone el grande comerssio de todos géneros que ay...» ${ }^{29}$. Era, por tanto, esa economía esencialmente gastadora que los juros alimentaban, capaz de activar hasta un cierto nivel los intercambios y la economía productiva, y de sostener a una numerosa población dependiente, la que corría verdadero peligro si fallaba — como estaba fallando- su fundamento principal.

Querer sostener la estimación de la deuda pública consolidada cuando al mismo tiempo se la estaban propinando los golpes que se han referido (crecimientos y reducciones del tipo de interés, sucesivos descuentos y valimientos) y cuando otras circunstancias concurrentes obraban asimismo en contra de dicho propósito (descenso del valor de las rentas que servían de situación a

28 AGS, CJH, leg. 852.

29 Las bajas de los juros y la caída de su cotización afectaban también a las contrataciones y a los negocios mercantiles en general, incluido el comercio de las Indias, pues muchos comerciantes no tenían otra hacienda en la que fundar su crédito para adquirir las mercancías que expedían que los títulos de la deuda pública consolidada. AGS, CJH, leg. 852. 
los juros, efectos de la inflación del vellón sobre capitales y réditos, etc.) constituía, ciertamente, un problema irresoluble al que las Cortes, por su parte, ninguna solución podían aportar que no fuera la de permitir, sin poner demasiadas objeciones, que se realizaran nuevas emisiones sobre los servicios (los de millones, sobre todo, pero también el servicio ordinario y extraordinario) que ellas mismas concedían. Tal expediente, que habría de pasar asimismo por extender el situado de los juros a las pocas rentas libres que le quedaban a la Corona o que ésta creaba ex novo sólo con ese fin, no bastó sin embargo para frenar el progresivo desprestigio de los juros, proceso éste que habría de manifestarse en primer término en las dificultades para colocarlos libremente en el mercado (de ahí el recurso a las ventas forzosas) y también en la imposibilidad de negociarlos a sus enteros precios, tanto a la hora de su emisión como después entre particulares, en el mercado secundario de títulos.

La propia Real Hacienda acabaría enredándose en la tela de araña que ella misma había ido tejiendo. Y no sólo (y ya era bastante) porque a la hora de liquidar las sucesivas suspensiones de pagos conforme a los medios generales concertados tuviese que entregar a los banqueros decretados juros contabilizados con una depreciación cada vez mayor o porque al compensar a los asentistas por sus asientos con juros se viese obligada a hacerlo estimándolos por debajo de su valor nominal ${ }^{30}$. Es que además, a partir de un determinado momento, la Corona, que había aceptado juros y medias anatas de juros como parte de pago para la compra de bienes y efectos que por su orden se enajenaban, dejó de hacerlo, consciente de los quebrantos que estas operaciones causaban al erario; el mismo Consejo de Hacienda se negaría a admitir, desde 1656, juros como fianza en los arrendamientos de rentas reales ${ }^{31}$, reconociendo así la fortísima depreciación que por entonces padecían, incluidos los impuestos en sucesivas emisiones sobre los servicios de millones. Títulos de nueva creación, como los emitidos a favor de los juristas en satisfacción o a cambio de los réditos de que Su Majestad se valía a raíz de los sucesivos va-

30 Así, por ejemplo, en el asiento formalizado el 30 de enero de 1628 con Antonio Balvi sobre la provisión de 2.600.000 escudos y ducados (2.000.000 en Flandes y 600.000 para la Armada), se le consignaron 400.000 ducados, equivalentes a 150.000 .000 mrs. en plata, en el precio de 8.365.000 mrs. de renta que se le habían de dar: los 2.020.000 en la propiedad y rentas de las alcabalas de Medina Sidonia que se le vendían a razón de a 24.000 el millar, y los 6.345.000 en juros de a 20.000 el millar sobre las alcabalas de Madrid «valuados a razón de a 16.000 el millar sin embargo de que su situación sea de a 20.000». AGS, CC. GG., leg. 122.

31 DOMÍNGUEZ ORTIZ, 1960: 329 nota 32. Había sido una práctica generalizada entre los hombres de negocios portugueses utilizar juros depreciados como fianza para conseguir arrendamientos de rentas de la Corona. Aunque la Real Hacienda no admitía estos juros a su entero valor nominal, sí les concedió durante un tiempo, antes del decreto suspensorio de 1647, una tasación más alta que la que era corriente en el mercado. Sanz Ayán, Carmen, “Hombres de negocios”, pág. 741 nota 33. 
limientos, serán rechazados incluso como moneda de cambio para el pago de tributos y otras contribuciones. Es lo que hizo, por ejemplo, el Consejo de Hacienda al desestimar, en consulta de 22 de diciembre de 1636, una propuesta realizada por don Gaspar de Bracamonte, comisionado para la recaudación del donativo de 1635 en la ciudad de Sevilla, consistente en admitir de los particulares ofrecimientos en los réditos de juros cuya paga se había suspendido «en la ocasión presente» para dar satisfacción de ellos en principales de juros de millones y otros. Señalaba el Consejo que aunque por este camino crecería el donativo, como suponía don Gaspar, «no será tan bueno el efecto como si se hiciera en dinero de contado y a plazos», pues para valerse de ello sería necesario vender la cantidad de juro que correspondiese a los réditos que se dieren en donativo, lo cual dudaba que se pudiera hacer si no era tasándolos por debajo del $50 \%$ de su valor nominal ${ }^{32}$.

Sea como fuere, lo cierto es que descuentos y valimientos de juros, si por una parte suponían un ingreso para la Hacienda, por otra mermaban la capacidad fiscal de los súbditos afectados, ya que provocaban, por la competencia que se establecía, que otras partidas del ingreso se resintiesen. Expresaba con claridad meridiana esta situación (tan frecuente por otro lado debido a la multiplicidad y diversidad de figuras fiscales existentes) el corregidor de Burgos en carta de 13 de agosto de 1638 al secretario de la Junta del Donativo, Juan Valero Díaz. Se quejaba el representante del rey de la especie que corría por la Corte según la cual no estaba prestando al juez que asistía en la ciudad a la cobranza del donativo todo el favor y ayuda que había menester cuando tal cosa no era cierta. Muy al contrario, tras describir a Burgos como lugar de "poco jugo y sustancia», donde todas las haciendas se componían de juros, «sin otro jénero ninguno de granjería» ${ }^{33}$, apuntaba en su descargo que, como después que se hubo pregonado el donativo había sobrevenido la orden de haberse valido el monarca de las medias anatas, era tanto el «aprieto» en que se hallaban los vecinos por esta razón que no era extraño que se hubiese retrasado o dilatado la paga de aquél. Él mismo se había ocupado en ir de casa en casa de todos los «deudores» a tratar de la cobranza, por lo que si las diligencias realizadas no habían surtido el efecto esperado no era precisamente a su persona a quien debían exigirse responsabilidades ${ }^{34}$. En fin, no hace falta insistir en que el propio acortamiento del comercio y de los intercambios, inducido, como ya

32 AGS, CJH, leg. 750.

33 Cuán diferente es esta imagen de Burgos de la de los siglos XV y XVI, cuando la caput Castellae hacía de bullanguera capital del llamado comercio del Norte y funcionaba como uno de los núcleos financieros y centro de seguros más activos de la península. Sobre este declinar y sus dimensiones, véase GONZÁLEZ PRIETO, 2005 y MARCOS MARTÍN, 2008: 54-55, especialmente el documento del AGS, CJH, leg. 561 que allí se comenta.

34 AGS, CJH, leg. 782. 
hemos señalado también, por la contracción del consumo y del gasto, se traducía para la Real Hacienda en un descenso de las percepciones no ya sólo en las aduanas, sino también en los servicios de millones y otros derechos.

En lo que no se ha puesto énfasis suficiente es en la inseguridad jurídica que estas actuaciones unilaterales de la Corona provocaban, de la misma manera que tampoco se ha intentado estimar su coste en el plano económico (y menos aún en los de la lealtad e integración políticas), una situación que cabe intuir se hallaba detrás de ese «desconsuelo» o «sentimiento» de los afectados de que hablan los documentos. No en balde, el comportamiento del monarca contravenía justamente lo que en los mismos privilegios de juros despachados por él y sus antecesores se aseguraba y prometía «por su palabra real», esto es, que los maravedíes de tales títulos no podrían ser «tomados, quitados ni rebocados, enbargados ni suspendidos ni puestos en ellos otro impedimento alguno», ni por leyes hechas en Cortes ni fuera de ellas, ni por otra forma ni manera alguna, si no fuera para consumirlos en la Corona pagando primero a las partes las cantidades que habían dado por ellos. Lo señalaba la ciudad de Sevilla en la carta de 1643 ya citada, en la que también recordaba a Felipe IV que acababa de prometer, como condición de la extensión del derecho de las alcabalas a todo lo arrendable concedida por las Cortes que se estaban celebrando (escritura de febrero de 1642), que no se había de valer de las cuartas partes, tercias y medias anatas de los juros y de los censos ${ }^{35}$. Sabemos, sin embargo, en qué pararon estas y otras promesas similares, de forma que no sería exagerado calificar aquella parte del articulado de los títulos de los juros que proclamaban tan solemnemente lo que no se podía hacer de ociosa, amén de innecesariamente prolija y redundante.

Así, pues, desprestigiada la deuda consolidada de los juros, por la depreciación y caída progresiva de su cotización y rentabilidad, la Monarquía, para cubrir sus necesidades y seguir captando el ahorro privado, amén de persistir mientras le fue posible en una política de escalada fiscal que conocemos relativamente bien, hubo de apelar a otros procedimientos, manipulando la deuda privada de los censos o sirviéndose de ella para expandir su propia capacidad de crédito.

Dado que se había establecido la media anata de los juros y que dicho arbitrio estaba produciendo, desde 1635 con regularidad, pingües beneficios, sobre todo si se cerraban los ojos a sus efectos negativos, nada mejor, debieron pensar algunos consejeros del monarca, que hacer lo propio con los censos propiedad de particulares y comunidades. Se recordará que las pragmáticas de reducción del tipo de interés de los juros comprendían también a los censos consignativos o al quitar, y que los motivos aducidos en ellas para justificar la adopción de semejantes medidas se hacían extensivos a éstos. Tales razones eran, al cabo, las mismas que se exponían en un largo «discurso» dirigido a

35 AGS, CJH, leg. 852. 
Felipe IV, sin fecha, pero muy probablemente de 1621, en el que se abogaba, entre otras medidas necesarias para la restauración del reino, por «subir» los censos, «de manera que los réditos sean tan pocos que todos gusten más de tratar y contratar con sus dineros que usarlos a çensos» ${ }^{36}$. Es decir, si estos contratos resultaban tan nocivos para la sociedad y la economía (e incluso para la virtud) como se pregonaba, estaba más que justificado tratar, por todas las vías posibles y, señaladamente, por la de la bajada del tipo de interés que los retribuía ${ }^{37}$, de que su volumen se redujera... Y también lo estaba, por qué no, el valerse Su Majestad de una parte de sus réditos, máxime si en el otro extremo de la balanza, para respaldar una medida tan drástica, se ponían las precisas necesidades que le apretaban.

Esta última posibilidad se planteó por primera vez, que sepamos, en el verano de 1637 con ocasión de la discusión de los medios para la provisión de los 11.098.000 escudos que se consideraban precisos para el gasto del año siguiente. De 29 de agosto de 1637 data, en concreto, una real cédula por la que se mandó cobrar el $25 \%$ de la renta de un año de los censos que había en los reinos de Castilla, excepto de los de 30 ducados abajo, dándose satisfacción a los dueños de lo que montase dicho descuento en juros de a 20.000 el millar contados a 16.000 en plata ${ }^{38}$. Dudas por despejar (especialmente la relativa a si los censos en manos de eclesiásticos debían contribuir) y dificultades de distinta naturaleza (empezando por la falta de un registro de censos fiable) impidieron entonces la ejecución de la cobranza. No obstante, justo al año siguiente, en respuesta a una consulta del Consejo de Hacienda de 15 de agosto de 1638, y contando ya con un registro de censos cuya elaboración se

36 Los ecos de las denuncias formuladas por algunos arbitristas contra los censos, especialmente por Martín González de Cellorigo, en su Memorial de la política necesaria, (1991), resuenan potentes en este discurso, como cuando, a modo de resumen conclusivo, su anónimo autor los tacha de «consumidores de las haçiendas, estragadores de las fuerças, destruidores de el tiempo, apagadores de la virtud, inçentivos del viçio y ofiçina de toda maldad. Por ellos [...] el Reyno padeçe». Discurso breve y sumario de las caussas porque se an disminuido y despoblado muchas villas y lugares en estos Reynos... GONZÁLEZ PALENCIA, 1932: 231-234 (doc. XLII).

37 Esta penalización de los censos para conseguir que el ahorro se desplazara hacia inversiones fecundas se había propuesto ya en un documento titulado Causas de la carestía de las cosas y remedios para ella, según informe de los corregidores en el año 1583, el cual se imprimió también por estas fechas, probablemente en 1620. Lo publicó igualmente GONZÁLEZ PALENCIA, 1932: 47 y ss. (doc. VIII).

38 La medida se acompañó de otra de la misma fecha que ordenaba cobrar el $25 \%$ de la renta de las casas en alquiler de Madrid, Sevilla, Córdoba, Toledo, Granada, Valladolid, Sanlúcar de Barrameda, Cádiz y Puerto de Santa María. Unos días antes, por real cédula de 16 de agosto, se había mandado percibir asimismo el $25 \%$ de la renta de un año de las alcabalas de permisión y de las que no tuviesen sus dueños títulos justos para gozarlas. AGS, CJH, leg. 773. 
había encomendado a los corregidores y justicias del reino, Felipe IV, por cédula de 30 de septiembre de $1638^{39}$, resolvió valerse de la mitad de la renta de los censos pertenecientes a seglares que rentasen más de 30 ducados (además de decretar una nueva media anata de juros de la que sacar otros 2.000.000 ducados en plata), dándose a sus propietarios la satisfacción arriba dicha ${ }^{40}$. Sin embargo, tampoco esta vez el intento cristalizó, y no precisamente por la resistencia tenaz de los propietarios afectados (en cuanto a los censos pertenecientes a eclesiásticos, por ejemplo, se convino finalmente que quedaran libres de contribuir) o por la falta de información necesaria (la confección de los registros y de los correspondientes sumarios se hizo con razonable eficacia y rapidez) ${ }^{41}$. Como había ocurrido antes y seguiría ocurriendo después con otras iniciativas fiscales de cuya retirada por la Corona los historiadores nos hemos apresurado a responsabilizar a la «resistencia» de las Cortes y de las oligarquías urbanas, o a supuestas limitaciones constitucionales del poder fiscal regio, fueron inconvenientes técnicos imposibles de salvar los que, a la postre, terminaron dando al traste con la pretendida media anata de los censos.

En efecto, según recordaba el Consejo de Hacienda en consulta de 17 de noviembre de 1638, que en esto seguía un dictamen preparado por el contador Tomás de Aguilar, la cobranza de la media anata de los juros no entrañaba demasiadas dificultades pues se hacía reteniendo sus réditos en los tesoreros y arrendadores (unos 200 en total) y cobrando de ellos antes de que los juristas se embolsasen el dinero, «con que no ay ocasión de tener pleito con el dueño ni le caussa el sentimiento que si después de hauer cobrado y enbolsado se le hubiera de bolber a sacar de su poder». En cambio, percibir una media anata de censos era cosa bien diferente no sólo porque el número de los deudores de quien se había de recoger el dinero era infinitamente más elevado, sino también porque los censualistas no cobraban en los plazos estipulados en los contratos sino muchas veces con esperas, ni lo hacían siempre en dinero sino en frutos de la tierra. En conclusión, era éste un expediente de complicada y dilatada cobranza, o por decirlo con las mismas palabras utilizadas por el men-

39 DOMÍNGUEZ ORTIZ, 1960: 364-370 (apéndice X), publicó los sumarios de algunos de estos registros, que él calificó como un «inventario parcial de los censos de Castilla». Nosotros hemos tenido la fortuna de encontrar datos más completos que han sido utilizados en otro lugar.

40 AGS, CJH, legs. 773 y 781.

41 Obviamente, también hay que descartar que las necesidades regias hubieran desaparecido de la noche a la mañana. En la reunión de la Junta del Aposento del condeduque celebrada el 4 de agosto de 1638 se estimaron las provisiones para 1639 en 14.300 .000 ducados, incluyendo en dicha cantidad 1.500 .000 ducados para acudir al ejército que se formaba contra los franceses que estaban en Guipúzcoa (consulta de 4 de agosto de 1638). AGS, CJH, leg. 782. 
cionado Tomás de Aguilar, un «medio espaciosso y no tan prompto como piden las necesidades» ${ }^{42}$.

Bastó, sin embargo, el anuncio de que Su Majestad mandaba registrar todos los censos y la sospecha añadida de que la operación no se hacía con una finalidad meramente informativa para que se produjera una crisis crediticia y el mercado del crédito se contrajera. Un ejemplo es suficiente para ilustrar lo que queremos decir. A finales de 1637 se concedió a la villa de Tudela de Duero facultad para tomar a censo los 5.073 .750 mrs. que se presupuso importaba la compra de su jurisdicción. La villa, en efecto, buscó y halló quien le prestase el dinero necesario, pero al llegar la noticia de que se había publicado el decreto para que se registrasen todos los censos, la persona que se había obligado a dar el referido censo se retiró. Sólo una condición le haría volver a su compromiso inicial: que la villa se responsabilizara a que si en algún tiempo el monarca, "por uia de enprestido o socorro o con otra cualquiera manera», se valiere de alguna parte de los réditos o del principal del censo, corriese por su cuenta el pago de lo que el tal descuento importare, «porque para él siempre an de estar sus réditos y principal, y libres y desenbargados corriendo a rraçón de cómo se fundaren». En resumidas cuentas, Tudela de Duero, para obtener la anhelada jurisdicción, señorío y vasallaje, debía plegarse a lo que el prestamista le imponía y solicitar, en consecuencia, una nueva licencia a fin de poder obligarse al censo con esta condición añadida, como efectivamente así lo hizo, no sin recordar el ejemplar de Daimiel, localidad que había gestionado con éxito, y por el mismo motivo, lo que ahora ella solicitaba ${ }^{43}$.

El Consejo de Castilla, por auto de 7 de noviembre de 1637, del que se despachó provisión, concedió a Tudela de Duero la referida facultad. A decir verdad, era lógico que así sucediese, pues según había advertido previamente la villa «si no se vale de este remedio no podrá pagar a V. Mgd. lo que es deudora» ${ }^{44}$. Y es que, ciertamente, no sólo estaba en juego la utilidad (o lo que fuere) de Tudela; la Corona se hallaba tanto o más interesada que la villa en que la concesión dicha tuviera lugar, pues era ella, al cabo, la destinataria última del capital que se tomaba a préstamo.

Casos como este de Tudela de Duero se dieron por doquier en el siglo XVII y vienen a confirmar la existencia de unas conexiones financieras entre la Hacienda regia y las haciendas municipales que, aunque venían de atrás, se multiplicaron e intensificaron sobremanera en el transcurso de la citada centuria. Tales conexiones, sobre cuya naturaleza y significado resta todavía mucho por decir, se ajustaban siempre a un mismo esquema, según el cual la

\footnotetext{
42 AGS, CJH, leg. 781. El informe de Tomás de Aguilar en el legajo 782.

43 AGS, CJH, leg. 785.

44 AGS, CJH, leg. 785.
} 
Corona autorizaba a los ayuntamientos a constituir censos sobre sus bienes de propios y rentas, y también, para financiar la deuda así contraída, a usar de arbitrios y expedientes diversos, siendo uno de los más socorridos, pero no el único, el de la imposición de sisas sobre productos de consumo masivo, generalmente artículos de primera necesidad. Es preciso insistir en que este recurso de las municipalidades al crédito a largo plazo, fuente de un creciente y persistente endeudamiento debido a las dificultades para redimir los censos emitidos, si bien en ocasiones tuvo su origen en la necesidad de allegar fondos para atender a asuntos domésticos - compras de trigo para el pósito, financiación de la lucha contra una epidemia, realización de obras públicas, pago de fiestas, etc.- las más de las veces estuvo provocado por las demandas dinerarias, directas o indirectas, del monarca. De esta forma, las haciendas locales se convirtieron en subsidiarias de la Hacienda de la Monarquía, o sea, fueron puestas sin remisión al servicio del crédito de la Corona, quien se sirvió de ellas para sostener y expandir su propia capacidad de crédito.

La literatura publicada hasta la fecha permite apreciar la cuantía de las ayudas ofrecidas al monarca en el transcurso del siglo XVII por algunas capitales de provincia en concepto de servicios y donativos ${ }^{45}$, dos términos empleados a menudo de forma indistinta en la documentación para designar aportaciones no muy diferentes en realidad, y que tienden a confundirse, a su vez, con los empréstitos propiamente dichos realizados igualmente por los concejos. Se insistirá de todas formas en que los núcleos de población que hacían tales transferencias al rey carecían por lo general de los dineros precisos con que realizarlas, por lo que debían pedirles prestados con anticipación. La solicitud a la Corona de las correspondientes facultades o autorizaciones para tomar a crédito las sumas en cuestión y el ofrecimiento a los prestamistas de las inexcusables garantías hipotecarias (generalmente los bienes y rentas de la localidad y a veces incluso los de los propios vecinos) constituían los primeros pasos a dar en esa dirección. De seguido (o al mismo tiempo) los esfuerzos se dirigían a la obtención de otro tipo de facultades regias, esto es, de licencias ora para hacer correr tal o cual arbitrio, ora para usar de este o aquel expediente, etc., mirando siempre a que la deuda emitida tuviera un mayor respaldo y resultase más atractiva a los ojos de los compradores, pero también - y sobre todo- a que su financiación en el porvenir fuera factible. Y quedaba, por último, la negociación con los representantes y consejeros del

45 Me refiero sobre todo a los trabajos de Bernardo Ares sobre Córdoba (1981), Fayard y De la Hoz sobre Madrid (1984 y 1988), Quintana Toret sobre Málaga (1988 y 1989), Gutiérrez Alonso sobre Valladolid (1987 y 1989), Martínez Ruiz sobre Sevilla (1992) o Burgos Esteban sobre Logroño (1994). Síntesis de los datos más importantes contenidos en estos trabajos han sido hechas por GUTIÉRREZ ALONSO, 1997: 187-211. GELABERT, 1997: 216 y ss. MARTÍNEZ RUIZ, 1975: 863-877. 
monarca de cara a la consecución de contrapartidas, habitualmente en forma de privilegios, los cuales, más que a la comunidad en su conjunto, buscaban beneficiar a la parte escogida de la misma, esto es, a los integrantes de las oligarquías locales, los mismos en definitiva que, para financiar la deuda contraída, conseguían poner en marcha un conjunto de exacciones y tasas que respetaba en buena medida sus rentas y patrimonios y desviaba la carga fiscal hacia otras bolsas, haciéndola recaer sobre la masa de los consumidores.

La venta de bienes y efectos del patrimonio público, desde tierras baldías a vasallos y jurisdicciones, pasando por oficios y cargos de todas las clases, rentas reales, privilegios y exenciones diversas, así como su adquisición más o menos forzada por parte de los concejos, activaron los mismos mecanismos en orden a propiciar y favorecer el endeudamiento de las haciendas municipales y consecuentemente la absorción, a su través, de capitales por parte de la Monarquía, con la subsiguiente contracción del mercado del crédito privado y merma de las posibilidades de inversión productiva; como sin duda indujeron también la aparición y despliegue de nuevas formas de extracción de renta o el ensanchamiento de las existentes ${ }^{46}$, hechos todos ellos que tuvieron que incidir necesariamente de un modo negativo en el proceso económico y social contemplado a medio y largo plazo.

Examinemos más de cerca estas cuestiones a la luz de un caso concreto, el que depara, durante algunos años del primer tercio del siglo XVII, la entonces declinante ciudad de Granada ${ }^{47}$. Por escritura de asiento de 11 de abril de 1614, la antigua capital nazarí se obligó a pagar 8.000 ducados de vellón por la merced que le hacía Su Majestad de perpetuarle y darle para propios tres oficios de corredores (uno del azúcar, arrieros y carreteros, y los otros dos del trigo, cebada y demás semillas que se vendían en la alhóndiga y del vino, vinagre y aceite), suma que entregó, en virtud de libranzas del Consejo de Hacienda, a diferentes hombres de negocios a cuenta de sus asientos. No fue ésta, empero, la única transacción que Granada realizó ese día con la Real Hacienda. Por una segunda escritura de la misma fecha, la ciudad se comprometió a pagar otros 2.000 ducados de vellón por la perpetuación de dos oficios de fieles ejecutores que tenía en cabeza de sendos veinticuatros, dándose a dicho importe idéntico destino que el anterior. De estos oficios se despachó título a Granada el 8 de junio, fecha en que se le concedió asimismo facultad para tomar a censo sobre sus propios los 10.000 ducados que se

46 Me he ocupado por extenso de esta cuestión en MARCOS MARTÍN, 2007: 161-210.

47 En carta de 20 de noviembre de 1635 dirigida a la Junta del Donativo en Madrid, don Luis Gudiel, comisionado para la cobranza del donativo de 1635 en el reino de Granada, al referirse a su capital decía que era una ciudad «tan poblada de jente como extenuada de caudales». AGS, CJH, leg. 729. 
había obligado a pagar ${ }^{48}$. Más aún, para que pudiera hacer frente al pago de los réditos de dicho censo, se le autorizó igualmente a usar del arbitrio del estanco de la nieve que se vendía en la ciudad, siempre y cuando no excediera de dos maravedíes por libra, y del de los sitios para cajones de madera en las plazas públicas, arbitrios de los que la ciudad venía usando para la paga de 9.000 ducados que debía por seis meses que dejó de imponer las sisas de los millones; y también licencia para adehesar y arrendar la hierba y bellota del monte de Chiclana, en el que ningún otro lugar tenía parte ni intereses ${ }^{49}$.

El 12 de julio se tomó nuevo asiento con Granada sobre que no se vendiesen, «perpetuamente en ningún tiempo», jurisdicciones en dehesas, cortijos, heredamientos, tierras, montes, olivares, viñas, riberos, ríos, pesquerías ni en otra cualquier cosa despoblada dentro de su distrito jurisdiccional más de las que hasta entonces se habían vendido, por lo cual ofreció servir con 20.000 ducados, que pudo pagar gracias a una facultad real de 5 de diciembre de 1615 que autorizaba a la ciudad a tomar a censo sobre sus propios y rentas la mencionada cantidad. Un último asiento, formalizado el 9 de octubre de 1614, concedió a la ciudad de Granada, a cambio de 2.000 ducados, el continuar perpetuamente en el uso en que estaba de nombrar a dos personas de su cabildo, veinticuatros o jurados, para otros tantos oficios de fieles ejecutores, además de los otros dos citados más arriba ${ }^{50}$.

En resumen, la capital granadina hubo de entregar en este año de 1614, por unos oficios que al fin y al cabo eran suyos (corredurías y fielazgos) y por algo tan vago e impreciso como la promesa del rey de no vender jurisdicciones de despoblados, un total de 32.000 ducados. La renegociación antes de concluir el año de los arbitrios concedidos para hacer frente al pago de los réditos de los censos emitidos determinó que al final no se usara del relativo a la dehesa de Chiclana, aunque a cambio se otorgó a la ciudad uno nuevo, concretamente el permiso para imponer un real en cada cabeza de carnero y macho cabrío que se rastrease en el rastro. Ignoro cuál fue el producto de estos arbitrios, y si con él se pudieron redimir los préstamos contraídos; pero me consta que todavía en 1647 el Consejo de Hacienda escribía a la ciudad para que enviase la cuenta de dichos arbitrios, conminándola a que no usase más de ellos hasta que no se prorrogasen formalmente ${ }^{51}$, lo que indica que prácticamente se habían perpetuado.

Al igual que otras ciudades y villas, Granada gastó también sumas considerables en intentar evitar, saliendo al tanteo, las amputaciones de su espacio jurisdiccional que sucesivamente se proyectaron. Ése fue el objetivo que alen-

48 AGS, DGT, invent. 24, leg. 1.487; y CJH, leg. 564.

49 AGS, DGT, invent. 24, leg. 1.487.

50 AGS, DGT, invent. 24, legs. 321 y 1.487; y CJH, leg. 564.

51 AGS, DGT, invent. 24, leg. 1.487. 
tó las compras, entre otros, de los lugares de El Padul y Cozvíjar que se habían vendido previamente a particulares. Así, en 1627, tras una carrera de pujas con don Martín de Aróstegui y el licenciado Gregorio López Madera, la ciudad adquirió el lugar de El Padul. Bajo la premisa de que tendría 60 vecinos y una legua de término, se obligó a pagar 2.981.250 mrs., incluidos 1.550 ducados que hubo de pujas. Sin embargo, hechas las averiguaciones pertinentes, el 30 de agosto de 1630 se ajustó la cuenta definitiva, conforme a la cual la ciudad hubo de pagar 5.025.463 mrs. de plata por las más de dos leguas que se midieron de término, que junto con 581.250 mrs. de las pujas, importó todo $5.606 .713 \mathrm{mrs}^{52}$. En cuanto al lugar de Cozvíjar, integrante como El Padul del señorío de Granada, fue comprado por la ciudad, mediante escritura de 7 de febrero de 1631, por los mismos 2.400 .000 mrs. estimados inicialmente. No obstante, y a pesar de que para su paga se le ofreció que se le daría facultad para usar de arbitrios, Granada no halló la manera de retener el lugar, y en 1641 se vio obligada a revenderlo al célebre jurista López Madera, que ya había pujado por él en 1631, año en que sí pudo hacerse con sus alcabalas ${ }^{53}$.

Como habían hecho antes y harían después otras localidades cabezas de jurisdicción, Granada pretendió acabar para siempre con los atentados que se cometían contra la integridad de su distrito jurisdiccional firmando un asiento y concierto con la Real Hacienda el 11 de octubre de 1633 para que en lo sucesivo no se vendiesen más vasallos de los lugares de su jurisdicción, ni la vara de alguacil mayor de ella; y también para que pudiese seguir nombrando los dos alguaciles y los demás oficios que su cabildo estaba en costumbre de nombrar. A cambio ofreció «servir» a Su Majestad con $24.750 .000 \mathrm{mrs}$. de vellón, pagaderos a ciertos plazos, los cuales fueron librados en su mayor parte a diferentes hombres de negocios. Pues bien, siguiendo la norma habitual en estos casos, uno de los capítulos del citado asiento contemplaba que, para la paga de dicha cantidad (así como de 1.650 ducados que importó la media anata de la «merced»), se daría a la ciudad facultad para tomarlos a censo sobre sus bienes de propios, rentas y arbitrios, como en efecto así se hizo. Más aún, para hacer frente al pago de los intereses de los censos se le dispensó asimismo facultad para vender ciertos censos (perpetuos) que tenía y para usar de cualesquier arbitrios que pidiese, sin limitación de tiempo, o sea, hasta tanto no redimiera la deuda contraída; además, mientras la concesión formal de tales arbitrios llegaba, podría servirse de los que se le asignaron (y estaba usando) con ocasión del último donativo ofrecido a Su Majestad ${ }^{54}$.

52 AGS, CJH, leg. 632; MP, leg. 251; y DGT, invent. 24, leg. 1.487. Asimismo, SORIA MESA, 1995: 117.

53 AGS, CJH, leg. 632; y DGT, invent. 24, leg. 1.487. Una copia de la escritura de venta de las alcabalas de Cozvíjar a López Madera en AGS, CC. GG., leg. 2.313, fol. 71 (11-111632), y del privilegio en CC. GG., leg. 919, fol. 21 (13-3-1634).

54 AGS, DGT, invent. 24, leg. 1.487. 
El otorgamiento de donativos y servicios extraordinarios solicitados por el monarca había supuesto (y seguiría suponiendo) para Granada, en efecto, nuevos y continuados desembolsos a los que sólo pudo hacer frente, como en tantas ocasiones en que se halló necesitada de dinero pronto, gracias al recurso al préstamo, sin desviarse tampoco en esto del modo de proceder de otras localidades. En 1629, por ejemplo, sirvió a su Majestad, «por vía de donativo» para las guerras de Italia, con 120.000 ducados de vellón, pagaderos en 10 años, para lo que otorgó escritura de obligación el 22 de enero de 1630 . Aunque en dicho servicio entraban otros dos hechos con anterioridad, uno de 25.000 ducados cuando Felipe IV visitó la ciudad, en que se subrogó a su vez el donativo de 1625, y otro bajo la forma de una leva de 600 soldados por un año ofrecido igualmente en 1629 , se trataba de una importante suma, que todavía en 1671 la ciudad no había satisfecho enteramente, a pesar de los arbitrios, a cada cual más dañoso, que se le concedieron para su paga y que empezaron a correr en $1630^{55}$. En fin, en este mismo año de 1630 Granada se obligó a contribuir también con otros 5.200 ducados de vellón por el valor de cuatro oficios de alguaciles y padre de menores que se habían vendido a diferentes personas y después se dieron por el tanto a la ciudad. Se trataba, en concreto, de la vara de alguacil del cabildo (2.000 ducados), de las varas de alguacil de las comedias de la puerta de las mujeres y de la puerta de los hombres (900 y 800 ducados) y del oficio de padre de menores (1.500 ducados $)^{56}$, que, como otros ya mencionados, la ciudad tenía por suyos.

Obviamente, no fueron las sumas referidas las únicas entregadas por la ciudad de Granada a la Corona a lo largo del siglo XVII por vías y conceptos diferentes, se precisará, de aquellos que fijaba la fiscalidad en sentido estricto. Y, por supuesto, tampoco constituyó Granada una excepción dentro de lo que fue, se insistirá también, la utilización generalizada por parte de la Monarquía de la capacidad de crédito de los municipios: todas las localidades, grandes y pequeñas, aunque lógicamente en una proporción diferente (es decir, en correspondencia más o menos directa al tamaño de su población y de su economía), se convirtieron en intermediarios financieros de la Corona, en garantes de unos préstamos hipotecarios cuyos principales a fin de cuentas tenían como destino, por distintas razones y motivos, la Tesorería regia, y de los que sólo surgían obligaciones para ellas, limitándose el monarca, además de a ser el receptor de aquéllos, a conceder las facultades para la constitución de los referidos censos y a permitir el establecimiento de las sisas y arbitrios necesarios con que poder hacer frente a los intereses de la deuda así contraída.

Se podrían poner, en efecto, centenares de ejemplos que demuestran fehacientemente esta supeditación de las haciendas municipales a la Hacienda

55 AGS, DGT, invent. 24, leg. 1.487.

56 AGS, DGT, invent. 24, leg. 1.487. 
pública de la que venimos hablando, su puesta al servicio del crédito del Estado. Quizá el más patente de todos sea el representado por los préstamos hechos al rey por algunos grandes municipios, los cuales no diferían en lo esencial, según se ha indicado ya, de los donativos y servicios extraordinarios que cumplimentaban el mismo recorrido, pues su reembolso, con el que se habían de amortizar algún día los censos contraídos para reunir las cantidades aportadas y pagar, mientras tanto, a los censualistas los intereses que fuesen cayendo, se hacía en ambos casos con el producto de arbitrios y rentas previamente concedidos por la Corona o a veces también, aunque más raramente, con el montante de impuestos estatales cuya gestión ésta cedía a las localidades. Por lo tanto, en vez de préstamos concedidos directamente por las ciudades al rey, se trataba más bien de préstamos hechos por particulares a su soberano, eso sí, con la intermediación de las ciudades, las cuales asumían la gestión de esta clase de deuda; préstamos en forma de censos, al cabo, que en el caso del Madrid de la segunda mitad del siglo XVII, por ejemplo, adquirieron una importancia creciente y desarrollaron características nuevas, en la medida sobre todo que debían ser amortizados en un plazo determinado y reportaban un interés más alto que el de los censos consignativos tradicionales $^{57}$. A su vez, también por estas mismas fechas comenzó a hacerse cada vez más frecuente la práctica de anticipar la recaudación del servicio de millones por parte de los ayuntamientos. Es decir, la Corona en lugar de apelar a los banqueros para que le adelantasen dinero sobre dicha consignación, recurría directamente al crédito de los particulares a través de los municipios: éstos se encargaban de reunir las sumas anticipadas mediante la emisión de censos situados sobre los mismos servicios de millones y, de paso, obtenían facultad para recaudar los impuestos sobre el consumo (sisas generalmente) a través de los que aquellos se instrumentaban, sirviendo su importe, finalmente, para retribuir a las personas que habían adquirido los $\operatorname{censos}^{58}$. Tales censualistas eran con frecuencia miembros de los propios regimientos, sus parientes y amigos (y en el caso de Madrid, además, consejeros y otros altos cargos de la administración central ${ }^{59}$ ), lo cual no dejaba de ser sino un exponente más (pues había otros) de las estrechas e interesadas vinculaciones que habían ido estableciéndose entre los grupos dominantes de las ciudades y la Real Hacienda.

Algunos de los servicios de millones creados en el transcurso del siglo XVII, como el de los 2,5 millones y, particularmente, el de quiebras, en vigor desde 1638, fueron satisfechos por no pocas localidades, una vez conocidas

57 Como supo ver FAYARD (1984, II: 253-265) al analizar los inventarios post mortem de los consejeros de Castilla.

58 ANDRÉS UCENDO, 1999: 183.

59 Además del trabajo de Fayard ya citado, véanse DE LA HOZ, 1988: 77-101. HERNÁNDEZ, 1995. LÓPEZ GARCÍA, 1998. 
las cantidades que se les repartía, mediante la contratación de censos sobre sus propios, lo que les llevaría a recurrir, para sostenerlos, a nuevas formas de fiscalidad local, cuando no a la venta y/o privatización del usufructo de sus posesiones territoriales ${ }^{60}$. Lo dicho para tales servicios (y, con ligeras variantes, para las quiebras experimentadas en la recaudación de otras rentas de la Corona, particularmente de las encabezadas) vale también para los socorros efectuados por los pueblos a compañías de soldados en tránsito, los pagos de alojamientos, bastimentos y pertrechos militares o los gastos por el levantamiento y sostenimiento de compañías o milicias armadas, sobre todo cuando tales dispendios se concebían como servicios hechos al monarca. Incluso si los desembolsos realizados lo eran en calidad de préstamos reembolsables por la Corona, la emisión de censos por parte de los concejos afectados constituyó un recurso no menos ineludible, pues las devoluciones prometidas solían retrasarse, si es que finalmente llegaban a producirse.

En fin, dentro del entramado de relaciones que vinculaba a los municipios con la Hacienda regia, cabe señalar que aquéllos podían figurar al mismo tiempo como emisores y compradores de deuda. Ocurría así en todos los casos en que, por ejemplo, las localidades solicitaban del monarca la concesión, a cambio del correspondiente servicio pecuniario, de arbitrios de donde sacar lo necesario con que comprar renta de juro o censo de la que pagar, a su vez, las sumas que les eran repartidas en concepto de servicio ordinario y extraordinario, alegando que, de esta manera, dicho servicio estaría «entero y sin diminución y la paga [de él] pronta y puntual», lo que redundaría además en beneficio del «bien público de la dicha villa, porque por el dicho medio los vecinos se relevarían de la dicha carga y sería ocasión de que se aumentasen y cesasen muchos pleitos e inconvenientes».

Los entrecomillados anteriores proceden del asiento concertado entre la Real Hacienda y Morón de la Frontera el 13 de junio de 1614 mediante el cual Su Majestad se servía hacer merced a dicha villa para que de los arbitrios que se declaraban pudiese abonar lo que debiere de servicio ordinario y extraordinario y sacar lo necesario para comprar 350.000 mrs. de renta a razón de a 25.000 el millar con la que en el futuro pagar puntualmente dicho servicio ${ }^{61}$. A cambio, Morón se comprometía a servir al monarca, de sus propios, con 22.000 ducados en reales de plata para fin de diciembre de 1614, amén de con otros 3.000 ducados de lo primero que procediese de los referidos arbitrios. Estos 22.000 ducados, junto con 1.000 ducados más para costas, podría tomarlos la villa a censo, hipotecando para ello, en virtud de la facultad que

60 Véase, por ejemplo, la interesante e ilustrativa relación de los «arbitrios otorgados a varios pueblos de la provincia de Toledo para el pago del servicio de las quiebras en la década de los 30», que publica ANDRÉS UCENDO, 1988: 249 y ss.

61 AGS, CJH, legs. 546 y 579. 
se le daba, sus propios, rentas y dehesas. Y no sólo eso. Para redimir dicho censo y pagar sus réditos, $\mathrm{y}$, sobre todo, para obtener 8.750 .000 mrs. con que comprar la citada renta (de juro o censo) capitalizada a razón de 25.000 el millar, se le concedía igualmente licencia para romper y arrendar hasta 4.000 fanegas de tierra de las dehesas de su término por tiempo de 16 años o, si el plazo no bastare, por el tiempo que más fuere menester ${ }^{62}$.

Fueron, pues, los bienes colectivos (dehesas y baldíos) los que pagaron la factura de la «compra» por Morón de la Frontera de su servicio ordinario y extraordinario. Servirían también dichos bienes para respaldar los 168.000 ducados en plata (8.000 de ellos para costas) que la villa tomó a censo en 1618 de diferentes particulares con el fin de pagar a Su Majestad la composición del pleito de sus alcabalas, censos por cierto que a comienzos del siglo XVIII, cuando la Junta de Incorporación procedió a revisar el privilegio de dichas alcabalas, todavía seguían en pie $^{63}$. No es necesario aventurar conclusiones acerca de quiénes salieron beneficiados de los rompimientos y arrendamientos de tales tierras; que lo fueran los mismos oferentes de los capitales tomados a préstamo o sus allegados, es bastante probable si atendemos a lo que apuntan en este sentido otros casos conocidos. Lo que es seguro e importa subrayar es que dicha política de endeudamiento, inducida por las necesidades regias, forzó cambios en el uso (y también en la propiedad) de los bienes colectivos de la villa, y, por ende, en las condiciones, que a partir de ahora se harían mucho más gravosas, con que los vecinos podían acceder a ellos, siendo los pequeños y medianos campesinos (por la modificación de la estructura de costes de sus explotaciones) y los jornaleros sin tierras los más perjudicados por tales mudanzas, impuestas, se repetirá, por la obligación de sostener la carga financiera de la deuda contraída.

Un vez más hay que insistir en el valor de ejemplar del caso traído a colación. Porque lo cierto es que fueron muchas las poblaciones que hicieron con sus bienes de propios y comunes lo mismo que Morón de la Frontera. Y que acudieron (no necesariamente como si se tratara de una práctica excluyente de la anterior, sino muy a menudo complementaria) a la imposición, con la debida anuencia regia, de sisas y arbitrios sobre el consumo de productos y artículos de primera necesidad. Esta fiscalidad a nivel local, que en no pocos casos tendió a perpetuarse, por la misma persistencia en el tiempo de la situación de endeudamiento inicial ${ }^{64}$, tuvo también, qué duda cabe, una incidencia negati-

62 AGS, CJH, legs. 546.

63 Se ajustó concierto con la villa el 2 de abril de 1618, el cual se insertó en el privilegio de dichas alcabalas, su fecha 27 de julio de 1620. AGS, CC. GG., leg. 899, fol. 34. Más información sobre este asunto en AGS, CJH, legs. 555 y 560.

64 Endeudamiento que a veces culminó, por imposibilidad material de seguir sosteniéndolo, en la venta de aquello que con tanto esfuerzo se había comprado. Se recordará que Domínguez 
va sobre las actividades productivas, tanto desde el lado de la oferta (al impulsar al alza los costes de producción y los salarios) como desde el lado de la demanda (al reprimir el consumo de los mismos bienes que gravaba), es decir, vino a acentuar y a ampliar los efectos negativos que en este mismo orden de cosas causaba la fiscalidad estatal, de naturaleza, como aquélla, predominantemente indirecta. En cualquier caso, y ya era una consecuencia suficientemente perniciosa, las emisiones de deuda por los ayuntamientos en forma de censos intensificaron el efecto desplazamiento de la inversión privada que el incesante crecimiento de la deuda pública de los juros provocaba y restaron aún más capitales a la inversión en la agricultura, la industria y el comercio ${ }^{65}$. Y, sin embargo, tal evidencia no empece para que pensemos que debió haber un momento, en las últimas décadas del siglo XVI, cuyos contornos cronológicos tendríamos que precisar mejor, en que la inversión en juros o en censos se erigió en una alternativa real a las escasas y menos rentables, ya entonces, oportunidades de inversión productiva, circunstancia que no haría sino retroalimentar aquel proceso y consolidar posiciones y comportamientos que habrían de revelarse determinantes para el porvenir, no obstante el progresivo deterioro y menoscabo de los títulos de uno y otro tipo de deuda a que se asistió a lo largo de la siguiente centuria.

\section{BIBLIOGRAFÍA}

Actas de las Cortes de Castilla publicadas por acuerdo del Congreso de los Diputados, XXVIII y XXIX, Madrid, Imp. De la Viuda e Hijos de J. A. García, 18771988.

Andrés Ucendo, José Ignacio, La fiscalidad en Castilla en el siglo XVII: los servicios de millones, 1601-1700, Bilbao, Universidad del País Vasco, 1999.

De la Hoz, Carlos, "Las reformas de la hacienda madrileña en la época de Carlos III”, en Equipo Madrid, Carlos III, Madrid y la Ilustración, Madrid, Siglo XXI, 1988; 77-101.

Ortiz (“La ruina de la aldea castellana”, págs. 1-26) construyó a partir de uno de estos casos, el de Redueña, lugar que en 1579 adquirió su jurisdicción y que no tuvo más remedio que venderse al mejor postor en 1627, el paradigma explicativo de ese proceso económico-social que el designó como «la ruina de la aldea castellana» (V. también AGS, DGT, invent. 24, leg. 1.468, fol. 1; y CJH, leg. 632). Pues bien, lo que hay que significar es que en aquella Castilla del siglo XVII hubo muchas otras «Redueñas», esto es, villas y lugares que para salir de las dificultades económicas en que habían incurrido se vieron obligadas a vender lo que habían comprado tras haber sufrido una importante mengua de población y de sustancia económica.

65 Obviamente, la toma de dinero a censo por los particulares (empezando por los grandes) para comprar activos del patrimonio público, componer mercedes o pagar servicios y donativos al rey trajo aparejadas las mismas consecuencias negativas, pero de esta cuestión no me he querido ocupar aquí. 
Domínguez Ortiz, Antonio, “La ruina de la aldea castellana”, Revista Internacional de Sociología, 24 (Madrid, 1948): 1-26.

Domínguez Ortiz, Antonio, Política y Hacienda de Felipe IV, Madrid, Editorial de Derecho Financiero, 1960.

Fayard, Janine, "Crédit public en Espagne au XVIIe siècle: les emprunts sur la ville de Madrid”, en Actas del II Coloquio de Metodología Histórica Aplicada. La documentación notarial y la Historia, Salamanca, Junta de Decanos de los Colegios Notariales de España, 1984, Vol, 2; 253-265.

Gelabert, Juan E., La bolsa del rey. Rey, reino y fisco en Castilla (1598-1648), Barcelona, Crítica, 1997.

González de Cellorigo, Martín, Memorial de la política necesaria y útil restauración a la república de España, ed. y estudio preliminar de José L. Pérez de Ayala, Madrid, IEF, 1991.

González Palencia, Ángel, La Junta de Reformación, Valladolid, Tipografía Poncelix, 1932.

González Prieto, Francisco J., La ciudad menguada: población y economía en Burgos (ss. XVI y XVII), Santander, Universidad de Cantabria, 2005.

Gutiérrez Alonso, Adriano, “Ciudades y monarquía. Las finanzas de los municipios castellanos en los siglos XVI y XVII”, en Luis Ribot y Luigi De Rosa (dirs.), Ciudad y mundo urbano en la época moderna, Madrid, Actas, 1997; 187-211.

Hernández, Mauro, A la sombra de la Corona, Madrid, Siglo XXI, 1995.

López García, José Miguel (ed.), El impacto de la Corte en Castilla, Madrid, Siglo XXI, 1998.

Marcos Martín, Alberto, "Deuda pública, fiscalidad y arbitrios en la Corona de Castilla en los siglos XVI y XVII”, en Carmen Sanz Ayán y Bernardo J. García García (eds.), Banca, crédito y capital. La Monarquía Hispánica y los antiguos Países Bajos (1505-1700), Madrid, Fundación Carlos de Amberes, 2006; 345-375.

Marcos Martín, Alberto, "Hipotecar la hacienda común. Enajenaciones del patrimonio regio y endeudamiento municipal en los siglos XVI y XVII”, en S. de Dios, J. Infante, R. Robledo y E. Torijano (coords.), Historia de la Propiedad. Crédito y garantía, Madrid, Servicio de Estudios del Colegio de Registradores, 2007; 161-210.

Marcos Martín, Alberto, "España en la primera mitad del siglo XVII: fuerzas, compromisos y debilidades”, en Saavedra Fajardo. Soñar la paz, soñar Europa, Murcia, Ayuntamiento de Murcia, Región de Murcia, CAM, 2008; 54-55.

Martínez Ruiz, José Ignacio, "Crédito público y deudas municipales en España (siglos XV-XVIII)”, en A. M. Bernal (ed.), Dinero, moneda y crédito en la Monarquía Hispánica, Madrid, Marcial Pons. Fundación ICO, 2000; 863-877.

Ripia, Juan de la, Práctica de la administración y cobranza de las rentas reales y visitas de los ministros que se ocupan de ellas, Madrid [1676], 1769.

Ruiz Martín, Felipe, “La banca en España hasta 1782”, en El banco de España. Una historia económica, Madrid, Banco de España, 1970; 1-196.

Ruiz Martín, Felipe, “Crédito y banca, comercio y transportes en la etapa del capitalismo mercantil”, en Actas de las I Jornadas de Metodología Aplicada de las Ciencias Históricas, III, Vigo, Universidad de Santiago de Compostela, 1975; 725-749. 
Sánchez Belén, Juan A., La política fiscal en Castilla durante el reinado de Carlos II, Madrid, Siglo XXI, 1996.

Sanz Ayán, Carmen, "Hombres de negocios y suspensiones de pagos en el siglo XVII”, en A. M. Bernal (ed.), Dinero, moneda y crédito en la Monarquía Hispánica, Madrid, Marcial Pons. Fundación ICO, 2000; 727-750.

Soria Mesa, Enrique, La venta de señoríos en el reino de Granada bajo los Austrias, Granada, Universidad de Granada, 1995.

Toboso Sánchez, Pilar, La deuda pública castellana durante el Antiguo Régimen (juros), Madrid, IEF, 1987.

Recibido: 21-11-2010

Aceptado: 01-07-2011 